\title{
Cold test on the vigor determination of Carthamus tinctorius L. seeds
}

\author{
Mirelle Vaz Coelho ${ }^{1} \odot$, Givanildo Zildo da Silva ${ }^{1 *}{ }^{\oplus}$, Ingrid Maressa Hungria de Lima e Silva² ${ }^{\circledR}$, \\ Rogério Borges de Oliveira $\mathrm{Paz}^{3}{ }^{\oplus}$, Amalia Andreza Sousa Silva ${ }^{1}{ }^{\circ}$, \\ Gabriela Fernandes Gama ${ }^{1} \odot$, Carla Gomes Machado ${ }^{1}$

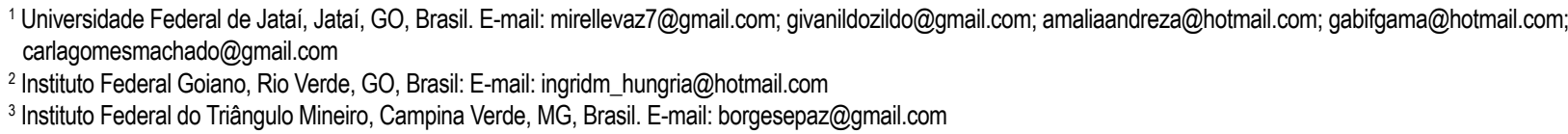

ABSTRACT: In evaluating the quality of seed lots, vigor tests are complementary to the germination test, identifying differences in their degree of deterioration. However, for safflower seeds (Carthamus tinctorius $L$.) there is little information regarding these tests. Thus, the objective was to adapt the cold test methodology to evaluate the vigor of safflower seeds. For that, twelve lots were initially characterized by moisture content, mass of one thousand seeds, germination and seedling emergence in the field. After characterization the samples were conditioned in transparent plastic boxes on paper moistened with water and kept at 10 ${ }^{\circ} \mathrm{C}$ for the periods of $0,3,5$ and 7 days. After the conditioning periods the samples were transferred to a germination chamber at $25{ }^{\circ} \mathrm{C}$, with evaluation of normal seedlings on the 3rd day. The obtained data was subjected to variation analysis and when significant, compared by the Scott-Knott method at $5 \%$ probability. To verify the efficiency of the methodologies, the principal component analysis was performed. The cold testing at $10{ }^{\circ} \mathrm{C}$ for 7 days is recommended for evaluating the physiological quality of safflower seeds.

Key words: physiological potential; quality control; Safflower

\section{Teste de frio na determinação do vigor das sementes de Carthamus tinctorius $L$.}

RESUMO: Na avaliação da qualidade de lotes de sementes os testes de vigor são complementares ao de germinação, identificando diferenças no grau de deterioração deles. No entanto, para sementes de cártamo (Carthamus tinctorius L.) há poucas informações em relação a esses testes. Assim, objetivou-se adequar a metodologia do teste de frio para avaliação do vigor de sementes de cártamo. Para isso, 12 lotes foram, inicialmente, caracterizados quanto ao grau de umidade, massa de mil sementes, germinação e emergência de plântulas em campo. Após a caracterização as amostras foram acondicionadas em caixas plásticas transparentes sobre papel umedecido com água e mantidos à $10^{\circ} \mathrm{C}$ nos períodos de $0,3,5$ e 7 dias. Após os períodos de acondicionamento as amostras foram transferidas para câmara de germinação à $25^{\circ} \mathrm{C}$, com avaliação de plântulas normais ao $3^{\circ} \mathrm{dia}$. Os dados obtidos foram submetidos a análises de variância e quando significativas comparados pelo método de Scott-Knott até $5 \%$ de probabilidade. Para verificar a eficiência das metodologias foi realizada a análise de componentes principais. $\mathrm{O}$ teste de frio à $10^{\circ} \mathrm{C}$ por sete dias é recomendado para avaliação do vigor de sementes de cártamo.

Palavras-chave: potencial fisiológico; controle de qualidade; Cártamo

\footnotetext{
* Gilvanido Zildo da Silva - E-mail: givanildozildo@gmail.com (Corresponding author)

Associate Editor: Edna Ursulino Alves
} 


\section{Introduction}

Safflower (Carthamus tinctorius L.) is an oleaginous, annual plant belonging to the family Asteraceae (Yao et al., 2018), which is used as an ornamental plant and also its flowers are employed in the production of natural dyes for food and textiles; the grains are used in bird feed and its bran in ruminant feed (Singh \& Nimbkar, 2016; Soleymani, 2017). The grain has oil content of 35 to $50 \%$ which is disseminated in the form of capsules in natura due to its health benefits, and is also intended for biodiesel production (Campanella et al., 2015).

The safflower plant has tolerance to saline soils, high temperatures, water deficit, and low humidity, making it an alternative for crop rotation (Bonfim-Silva et al., 2015; Bidgoly et al., 2018). It is propagated by seeds, which are one of the main agricultural inputs. Thus, its quality is one of the primary factors for the establishment of the crop in the field, so it is essential to evaluate its physiological potential through germination and vigor tests (Frandoloso et al., 2017). However, the germination test is conducted under optimal conditions, expressing the maximum potential of the seed lot, while in vigor tests the seeds are subjected to adverse conditions and may express more subtle attributes not evidenced by the germination test.

Among the vigor tests, the cold test is widely used, especially for corn, and because of the reliability of the results provided, there is interest in standardizing it for other species. This stress test has as its basic principle the exposure of seeds to low temperature and high humidity (Marcos Filho, 2015).

In the literature there is indication of the periods of three, five and seven days to perform the cold test on seeds of cotton (Gossypium hirsutum L.), soybean (Glycine max L.), maize (Zea mays L.) and cardamom, respectively (Barros et al., 1999; Kaya et al., 2019). Thus, studies varying the conditioning times are necessary, aiming to reduce this time, since the faster the result, the better the destination dynamics of the seed lots. In view of the above, the objective was to adapt the cold test methodology to evaluate safflower seed vigor.

\section{Materials and Methods}

The safflower seed lots used were 12, from the second 2017/2018 harvest in the University Farm of the Federal University of Jataí, Goiás, Brazil, which were sent to the Seed Analysis Laboratory of the same institution, where the analyses were conducted.

The samples were initially homogenized using the soil type divider, passing them three times through the apparatus, which were divided until four sub-samples were obtained, which corresponded to the repetitions, and then evaluated and the following tests and determinations were performed:

Moisture content: determined by the oven method $105 \pm$ $3{ }^{\circ} \mathrm{C}$ for 24 hours, using two sub-samples for each lot (Brasil, 2009).
Thousand seed mass: were weighed, on precision analytical scales $(0.001 \mathrm{~g})$, in four repetitions of eight sub-samples of 100 seeds for each lot, after obtaining the prescribed RAS (Brasil, 2009).

Germination test: eight repetitions of 25 seeds were sown in transparent acrylic boxes with lids $(11.0 \times 11.0 \times 3.5 \mathrm{~cm})$ containing "blotting paper" as substrate type, then the seeds were covered with one of the same paper, moistened with a volume of water $(\mathrm{mL})$ equivalent to 2.5 times the mass of dry paper (g) (Brasil, 2009). The final count on the eighth day after the test installation (Gama et al., 2019) counting the number of normal, abnormal and dead seedlings, as described in the RAS (Brasil, 2009).

First count of germination: performed in conjunction with the twinning test, with a count of the number of normal seedlings on the third day after the test was installed (Gama et al., 2019).

Seedling emergence test in the field: two tests were performed, and in each one four subsamples of 50 seeds per lot were sown in furrows one meter long, and the first test occurred during October/November 2018, with a depth of two centimeters at sowing, and the second in March/April 2019 , with a depth of four centimeters, whose moistening was only on the day of sowing. Evaluations were made by counting the emerged normal seedlings (those with cotyledons above ground) daily after sowing until seedling emergence stabilized in each plot, calculating the percentage of seedling emergence in the field, and also evaluating:

First emergence count - counted when $50 \%+1$ of the total seedlings emerged for most plots.

Emergence velocity index (EVI) - calculated from the daily count data of emerged seedlings from the field emergence test and determined using Maguire formula (1962).

Initial, final, mean, and relative frequency of seedling emergence - using the data from the daily count of emerged seedlings, whose initial and final times corresponded to the first and last day of emergence after sowing, respectively, for each plot. For the mean time and relative frequency of emergence we used the formulas described by Santana \& Ranal (2004).

Cold test: 12 lots of seeds were evaluated and sown following the same methodology described above, using four sub-samples of 25 seeds for each lot. The acrylic boxes were kept in a germination chamber regulated at $10{ }^{\circ} \mathrm{C}$ for four periods $\left(0,3,5\right.$, and 7 days), then placed at $25^{\circ} \mathrm{C}$, and a count of normal seedlings was performed on the third day after the test was installed (Barros et al., 1999; Brazil, 2009; Gama et al., 2019).

The data obtained in the initial characterization and in the cold test, in which the 12 lots were evaluated within each period, in independent experiments, were submitted to variance analysis at $5 \%$ probability using the $F$ test, and for grouping the means the Scott-Knott method was used at $5 \%$ probability. The data was tested for normality and homogeneity and when necessary was transformed into $(x+0.5)^{0.5}$, and the original data is shown in the table. To verify 
the efficiency of the methodologies, principal component analysis was performed, processed in the $\mathrm{R}$ program.

\section{Results and Discussion}

The seeds of the 12 lots of safflower had an average moisture content of $5.6 \%$ with a variation of less than $1 \%$ between seeds of the lots (Table 1), whose values are within the range of variation of four percentage points, which confers reliability to the test results. The similarity of seed moisture content values is paramount so that quality analysis tests are not affected by differences in metabolic activity, wetting speed, and seed deterioration intensity (Marcos Filho, 2015).

In the initial characterization by determining the mass of one thousand seeds and the germination and seedling emergence tests in the field, there was significance only for the variables: dead seeds, emergence, and seedling emergence speed index in the field, at a depth of two centimeters. It is noteworthy that the mass of one thousand seeds was between 33.03 and $35.53 \mathrm{~g}$, while the emergence was between 77 to $93 \%$ for a depth of two centimeters and 70 to $82 \%$ when sown at a depth of four centimeters.

The germination percentage was between 77 and 94\%, remaining higher than $60 \%$, which is the minimum required for the production and marketing of seeds of major crop species entered in the national register of cultivars not contemplated with a specific standard, such as safflower (Brasil, 2013). It is still important that the samples evaluated have similar germination, in the present work it was 92 $\pm 4 \%$, and compatible with the standards established for commercialization, since one of the objectives of vigor tests is to identify significant differences in the physiological quality of marketable lots with similar germination (Marcos Filho, 2015).

The lowest percentage of dead seeds occurred in lots 1 , 3,4 , and 7 , while the other lots showed a higher percentage (Table 1). The RAS define dead seeds as those that at the end

Table 1. Seed moisture content (SMC), dead seeds (DS), emergence $(E 2 \mathrm{~cm})$ and emergence velocity index of seedlings from sowing at a depth of two centimeters (EVI $2 \mathrm{~cm}$ ) of twelve lots of safflower seeds.

\begin{tabular}{ccccc}
\hline \multirow{2}{*}{ Lots } & TA & DS & E 2cm & \multirow{2}{*}{ IVE 2cm } \\
\cline { 2 - 4 } & & (\%) & & \\
\hline 1 & 6.18 & $2 \mathrm{~b}$ & $80 \mathrm{~b}$ & $8.93 \mathrm{~b}$ \\
2 & 5.94 & $9 \mathrm{a}$ & $77 \mathrm{~b}$ & $8.63 \mathrm{~b}$ \\
3 & 5.47 & $2 \mathrm{~b}$ & $80 \mathrm{~b}$ & $9.00 \mathrm{~b}$ \\
4 & 5.57 & $2 \mathrm{~b}$ & $87 \mathrm{a}$ & $9.77 \mathrm{a}$ \\
5 & 5.57 & $7 \mathrm{a}$ & $87 \mathrm{a}$ & $9.70 \mathrm{a}$ \\
6 & 5.79 & $7 \mathrm{a}$ & $87 \mathrm{a}$ & $9.44 \mathrm{a}$ \\
7 & 5.47 & $1 \mathrm{~b}$ & $93 \mathrm{a}$ & $10.56 \mathrm{a}$ \\
8 & 5.55 & $8 \mathrm{a}$ & $88 \mathrm{a}$ & $9.58 \mathrm{a}$ \\
9 & 5.63 & $11 \mathrm{a}$ & $85 \mathrm{a}$ & $9.57 \mathrm{a}$ \\
10 & 5.62 & $7 \mathrm{a}$ & $85 \mathrm{a}$ & $9.52 \mathrm{a}$ \\
11 & 5.23 & $9 \mathrm{a}$ & $79 \mathrm{~b}$ & $8.88 \mathrm{~b}$ \\
12 & 5.69 & $5 \mathrm{a}$ & $88 \mathrm{a}$ & $9.99 \mathrm{a}$ \\
CV (\%) & - & 45.35 & 5.87 & 6.60 \\
\hline
\end{tabular}

Means followed by the same letter do not differ by the Scott-Knott method at $5 \%$ probability. - Not submitted to statistical analysis. CV: Coefficient of variation. of the test do not germinate, are neither hard nor dormant, and generally present themselves as softened and attacked by microorganisms (Brasil, 2009). However, each individual seed was not evaluated by the tetrazolium test, so when they were opened and observed they could be either dead or malformed (empty).

In the emergence test at a depth of two centimeters it was possible to classify lots 1, 2, 3 and 11 as less vigorous, however, there was divergence between the tests when sowing in different environmental conditions and depth, even though the same lots of safflower seeds were used. The divergence of results of the field seedling emergence test was also seen in work by Maziero et al. (2019) who obtained difference in the percentage and speed of emergence index analyzing six safflower cultivars.

In the emergence of seedlings in the field, at a depth of two centimeters, the polygons of the relative frequency of emergence (Figure 1) showed that the seedlings began to emerge on the 3rd day after sowing. The behavior of the distribution was unimodal, with only one peak, for all lots, demonstrating high uniformity of the initial stand. Through the frequencies, according to Santana \& Ranal (2004) it is possible to observe if over time the seeds germinate until they reach a maximum value and then decline.

In all plots studied it can be seen that emergence was concentrated in the periods from three to six days after sowing (Figure 1), and in plot 6 a peak of emergence was observed on the fifth day and the highest percentage of relative frequency. For the other lots, the peak of seedling emergence was between the fourth and fifth day, when the highest percentage was observed.

In the emergence of seedlings in the field, at a depth of four centimeters, it was verified by the polygons of the relative frequency of emergence, that the seedlings began to emerge between the $6^{\text {th }}$ and $7^{\text {th }}$ day after sowing, while the time to the last emergence varied from 11 to 14 days (Figure 2). The behavior of the distribution was polymodal, with more than one peak in emergence, except for lot 8, showing that there was no homogeneity in emergence. This fact is explainable because the germination process is not perfectly synchronized, distributing itself over time (Oliveira et al., 2017). There was no displacement of the polygon in any of the cases, since the mean times were similar, but in general, the displacement of the polygonal line to the right or left of the mean time, evidences a delay in the germination process, as a result of a reduction in seed vigor (Berger et al., 2014).

The second emergence of seedlings in the field, unlike the first, was concentrated in different periods, which started later and continued for a longer period. This divergence can be explained, since in addition to a longer dry period in the second emergence the depth was greater $(4 \mathrm{~cm})$ than in the first $(2 \mathrm{~cm})$. The emergence peaks were related to the rainfall periods, thus demonstrating that the seedling emergence test in the field varies according to the seasons and environmental conditions of the environment, making this test difficult to standardize, so its use as a standard for defining the methodology of vigor tests can lead to errors (Figure 2). 


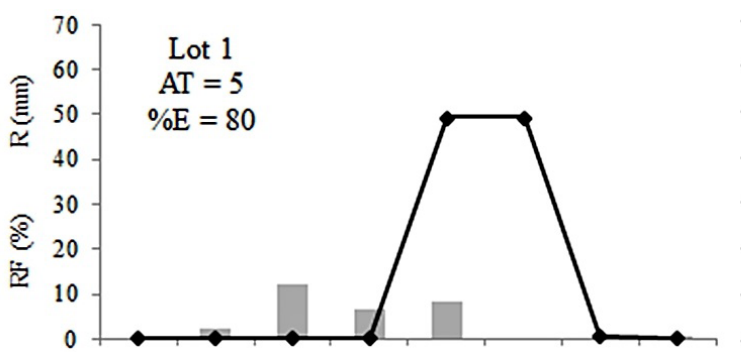

Lot 7

$\mathrm{AT}=5$

$\% \mathrm{E}=93$
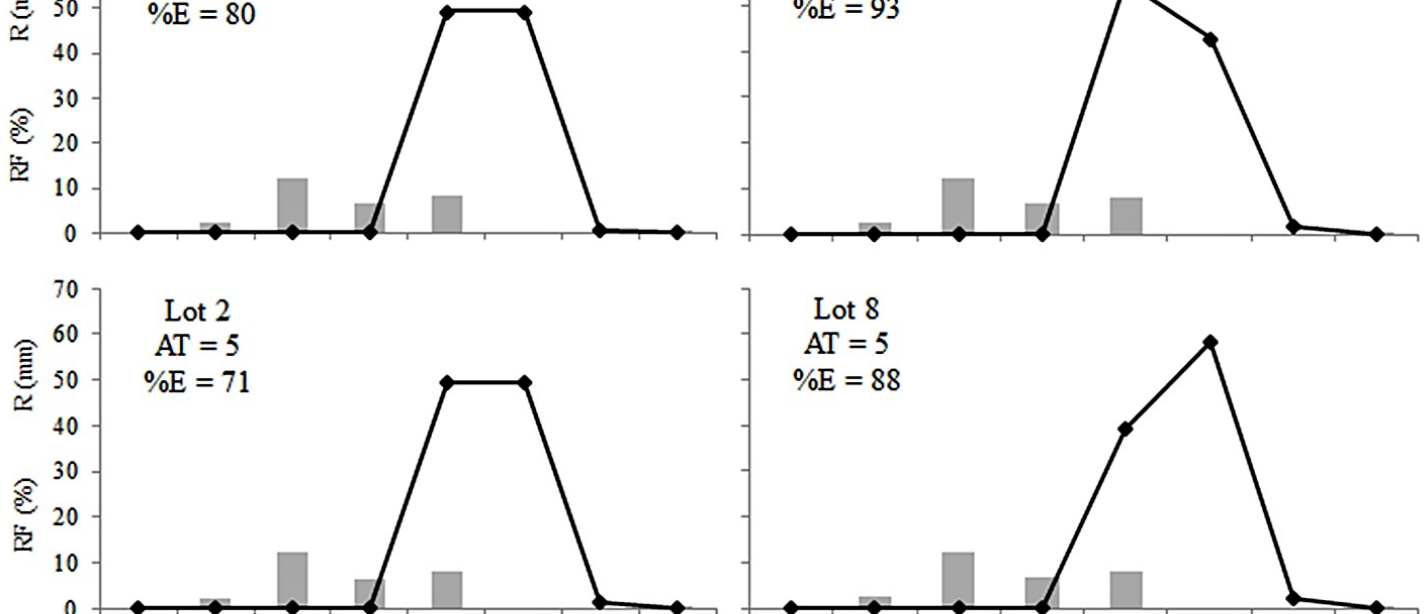

\section{Lot 8}

$\mathrm{AT}=5$

$\% \mathrm{E}=88$
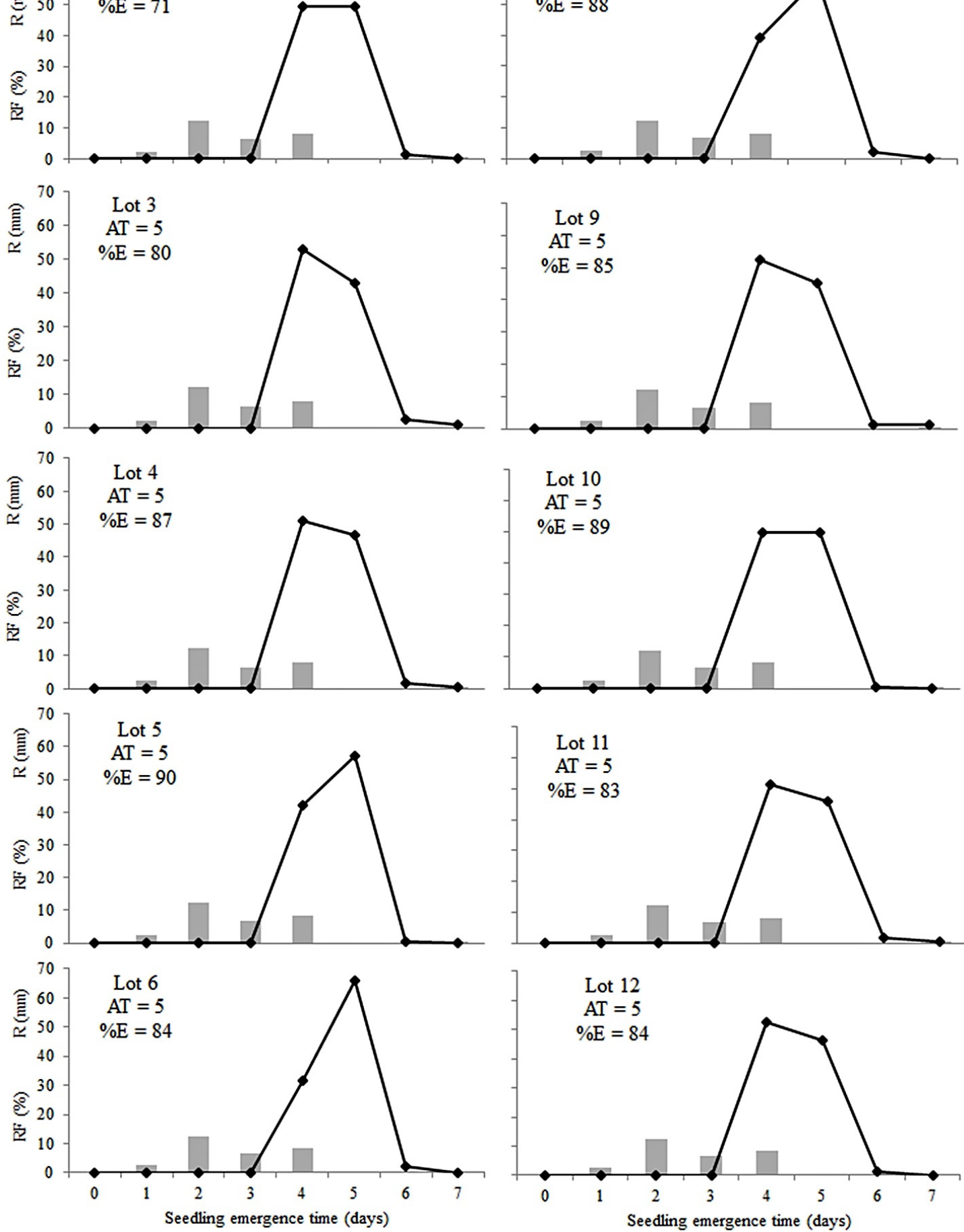

Lot 10

$\mathrm{AT}=5$

$\% \mathrm{E}=89$
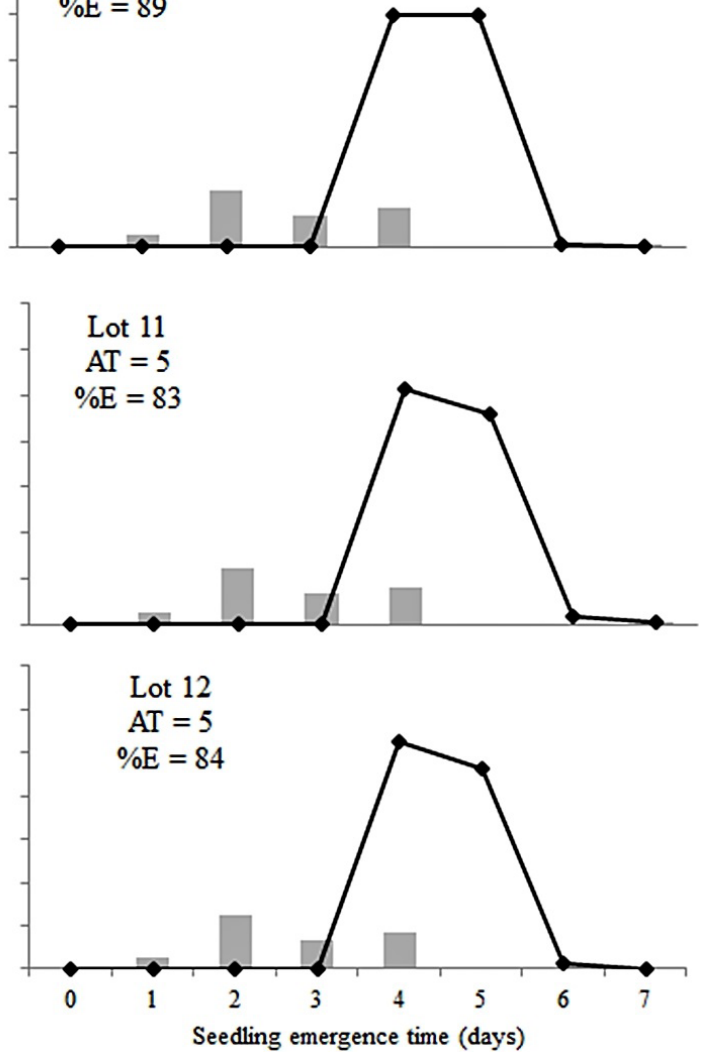

$\mathrm{AT}=$ average germination time; \% $=$ emergence percentage. Precipitation data (INMET, 2019).

Figure 1. Relative frequency distribution (RF) of seedling emergence of 12 lots of safflower seeds sown in a field two centimeters deep and rainfall $(R)$ during the course of the experiment. 


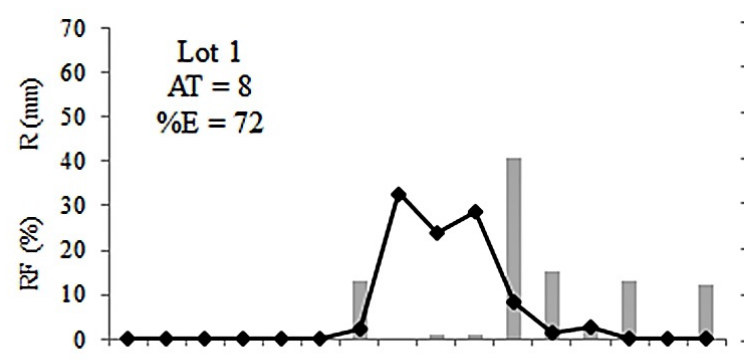

Lot 7

$\mathrm{AT}=9$

$\% \mathrm{E}=82$

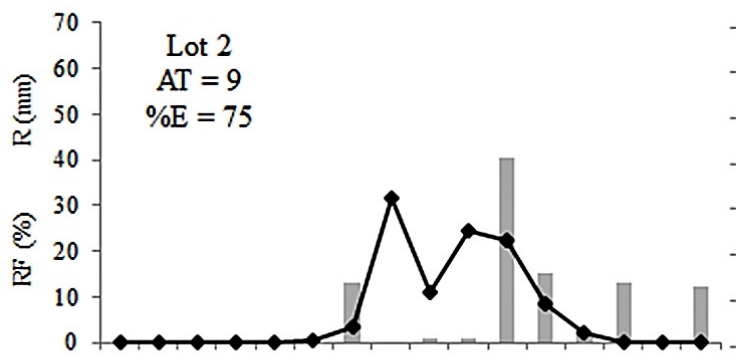

Lot 8

$\mathrm{AT}=9$

$\% \mathrm{E}=77$

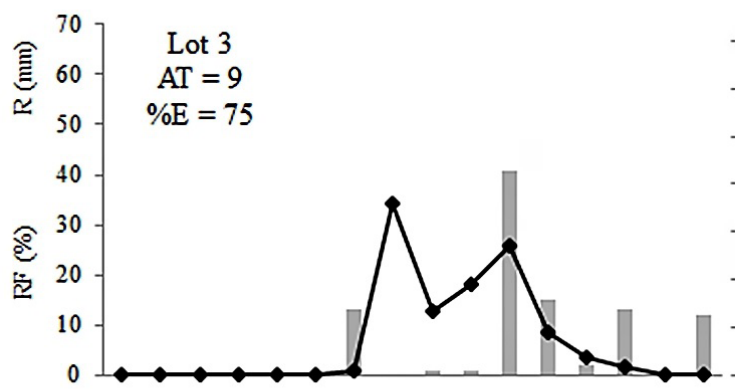

Lot 9

$\mathrm{AT}=9$

$\% E=75$

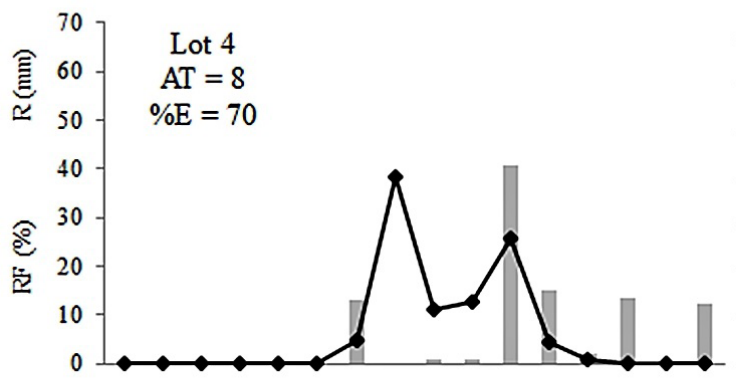

Lot 10

$\mathrm{AT}=9$

$\% \mathrm{E}=78$

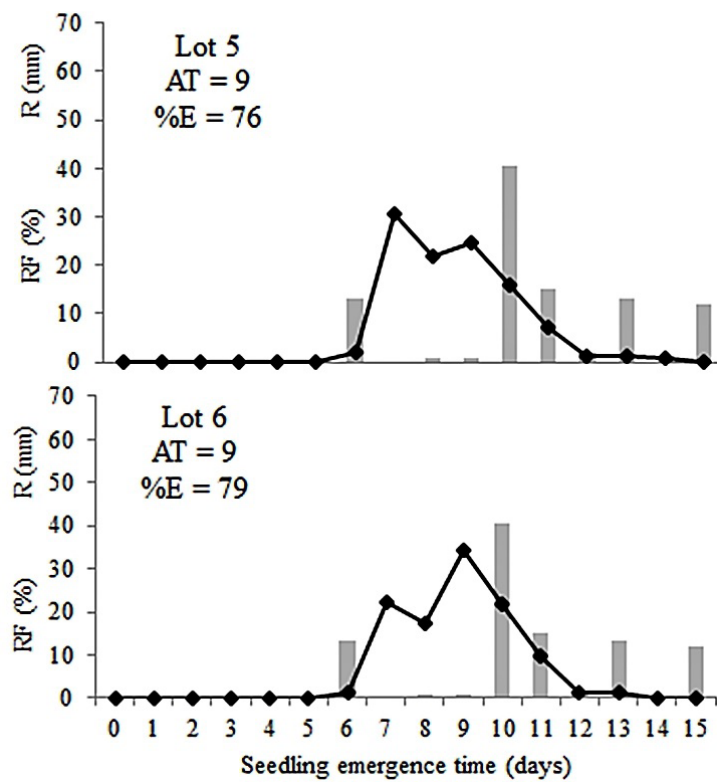

Lot 11

$\mathrm{AT}=9$

$\% \mathrm{E}=80$

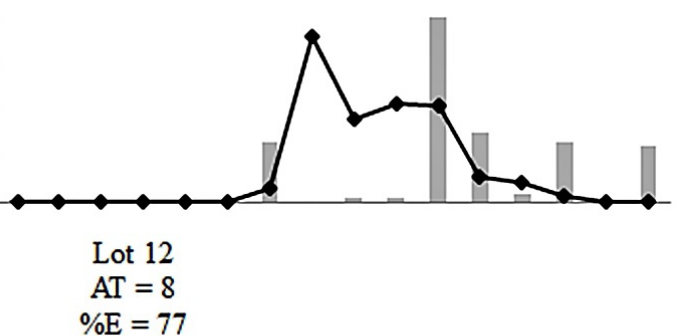

$\% \mathrm{E}=77$

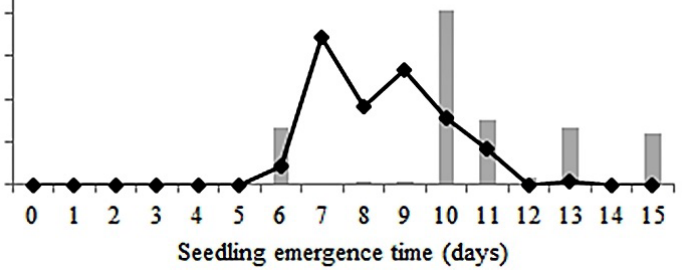

AT = average germination time; \%E = emergence percentage. Precipitation data (INMET, 2019).

Figure 2. Relative frequency distribution (RF) of seedling emergence of 12 lots of safflower seeds sown in a field four centimeters deep and rainfall $(R)$ during the course of the experiment. 
Regarding the cold test it was observed that the 12 lots differed statistically within the periods 3, 5, and 7 days (Table 2 ). The average results of 82,81 , and $82 \%$ normal seedlings at 3,5 , and 7 days, respectively, indicated the high physiological quality of the seeds, since, even under stress conditions, the germination percentage remained higher than $60 \%$. This percentage is the minimum required for the production and marketing of seeds of major crop species registered in the national register of cultivars not contemplated with a specific standard, such as safflower (Brasil, 2013).

At three days of conditioning at $10{ }^{\circ} \mathrm{C}$ (Table 2), the seeds were stressed, ranking the lots in four levels of vigor, with lots $3,7,8,9$, and 11 classified as most vigorous, then lots 4, 5, 6, 10 , and 12 as medium-high vigor, followed by lot 1 , mediumlow vigor, and lastly lot 2 as low vigor. In the five-day period after the stress period, for plots $1,2,4,8,10$, and 11 the lowest percentage of normal seedlings was found, differing from plots $5,6,7$, and 9, which were intermediate to the others; thus, plots 3 and 12 were the most vigorous. At seven days, the plots were stratified into four levels, with a higher germination percentage of seeds from plots 7,8 , and 9 , being the most vigorous, then plots $1,3,5,10,11$, and 12 , classified as medium-high vigor, which were higher than plots 4 and 6 , medium-low vigor, which differed from plot 2 , these being low vigor.

In the 5-day period the cold test differentiated the safflower seed lots into three groups, however, the 3 and 7-day periods stratified the lots into four levels of vigor, thus being more promising (Table 2).

In the principal components analysis (Table 3), three components were found to account for $73.98 \%$ of the accumulated variation, in which the first component accounted for $39.99 \%$, the second for $19.86 \%$, and the third for $14.13 \%$ of the data variation. Similarly, Lorentz \& Nunes (2013), working on vigor in rice seeds, found the need for three principal components for representativeness of their data by using the same analysis.

The accumulated variance close to $70 \%$ was verified in studies on vigor tests for seeds of other species, for example

Table 2. Germination (\%) of seeds from twelve lots of safflower after four conditioning periods $(0,3,5$, and 7 days $)$ at $10^{\circ} \mathrm{C}$ temperature for the cold test.

\begin{tabular}{ccccc}
\hline \multirow{2}{*}{ Plots } & \multicolumn{4}{c}{ Conditioning periods (days) } \\
\cline { 2 - 5 } & 0 & 3 & 5 & 7 \\
\hline 1 & $94 a$ & $76 c$ & $75 c$ & $80 b$ \\
2 & $77 a$ & $67 d$ & $71 c$ & $63 d$ \\
3 & $91 a$ & $90 a$ & $92 a$ & $81 b$ \\
4 & $80 a$ & $79 b$ & $73 c$ & $76 c$ \\
5 & $87 a$ & $81 b$ & $83 b$ & $82 b$ \\
6 & $87 a$ & $82 b$ & $83 b$ & $73 c$ \\
7 & $88 a$ & $88 a$ & $85 b$ & $93 a$ \\
8 & $82 a$ & $87 a$ & $77 c$ & $91 a$ \\
9 & $84 a$ & $87 a$ & $85 b$ & $93 a$ \\
10 & $82 a$ & $83 b$ & $75 c$ & $84 b$ \\
11 & $83 a$ & $88 a$ & $79 c$ & $84 b$ \\
12 & $90 a$ & $80 b$ & $92 a$ & $87 b$ \\
\hline
\end{tabular}

Means followed by the same letter in the column do not differ by the Scott-Knott method at $5 \%$ probability.
Table 3. Matrix of eigenvectors and eigenvalues of principal components (PC) and evaluation of physiological quality of seeds from 12 lots of safflower with emphasis on the cold test.

\begin{tabular}{lrrr}
\hline \multicolumn{1}{c}{ Variables } & CP1 & \multicolumn{1}{c}{ CP2 } & \multicolumn{1}{c}{ CP3 } \\
\hline First count of germination & $\mathbf{0 . 3 5}$ & 0.35 & $-\mathbf{0 . 4 7}$ \\
Germination & $\mathbf{0 . 3 2}$ & $\mathbf{0 . 5 1}$ & -0.18 \\
\hline Seedling emergence in the field 2 cm & $\mathbf{0 . 3 2}$ & -0.20 & 0.29 \\
\hline First count of seedling emergence in the & $\mathbf{0 . 3 1}$ & 0.23 & 0.38 \\
field 2 cm & 0.22 & $-\mathbf{0 . 4 5}$ & $-\mathbf{0 . 6 0}$ \\
\hline Seedling emergence in the field 4 cm & 0.24 & 0.34 & $\mathbf{0 . 5 1}$ \\
\hline First count of seedling emergence in the & $\mathbf{0 . 3 7}$ & $-\mathbf{0 . 3 8}$ & -0.11 \\
field 4 cm & $\mathbf{0 . 3 9}$ & -0.09 & -0.42 \\
\hline 3-day cold test & $\mathbf{0 . 4 3}$ & -0.22 & 0.23 \\
5-day cold test & 3.60 & 1.79 & 1.27 \\
7-day cold test & 39.99 & 19.86 & 14.13 \\
\hline Eigenvalues & 39.99 & 59.85 & $\mathbf{7 3 . 9 8}$ \\
\hline Variance (\%) & & \\
Cumulative variance (\%) & & \\
\hline
\end{tabular}

Representative component variables based on the modulus of the $0.5 /(\lambda)^{0.5}$ ratio, highlighted in bold (Collins \& Ovalles, 1988).

soybean (Barbosa et al., 2013) and Urochloa decumbens (Silva et al., 2019), whose value was indicated by Rencher \& Christensen (2012) for determining the number of components to be adopted.

The eigenvectors between the original variables and the principal components were calculated, according to this assumption by Collins \& Ovalles (1988), and eigenvectors greater than $0.26,0.37$, and 0.44 were considered significant for components 1,2 , and 3, respectively, that is, variables with eigenvectors equal or greater are those that contribute to the accumulated variance in that component.

Only the variables emergence and first count of seedlings in the field sown at $4 \mathrm{~cm}$ had no discriminatory power for principal component 1 (Table 3). The cold test variables for 3 , 5 , and 7 days correlated with the two field emergence tests, since their vectors are in the same direction and quadrant, as well as forming acute angles with each other (Figure 3). The cold test for 7 days was promising in the evaluation of safflower seeds, since the highest eigenvector was obtained in principal component 1 (Table 3, Figure 3).

The variables germination, emergence of seedlings in the field sown at $4 \mathrm{~cm}$ and cold test for 3 days had discriminatory power for principal component 2 (Table 3), with a higher correlation between the last two, by the acute angle formed between their vectors. However, the variable cold test for 3 days, even with discriminatory power for principal component 2 , has a negative sign. Therefore, the higher the percentage of seedlings obtained after the cold test, the lower the values of the germination variable, so that this variable would not be efficient to evaluate the quality of safflower seeds.

In principal component 3 , the variables that had the highest discriminatory power were first count of germination, emergence, and first count of seedlings in the field sown at $4 \mathrm{~cm}$ depth (Table 3). As the number of components used increases the accumulated variance is reduced, therefore, the variables in these components would have less discriminatory power in the evaluation of safflower seed lots. 


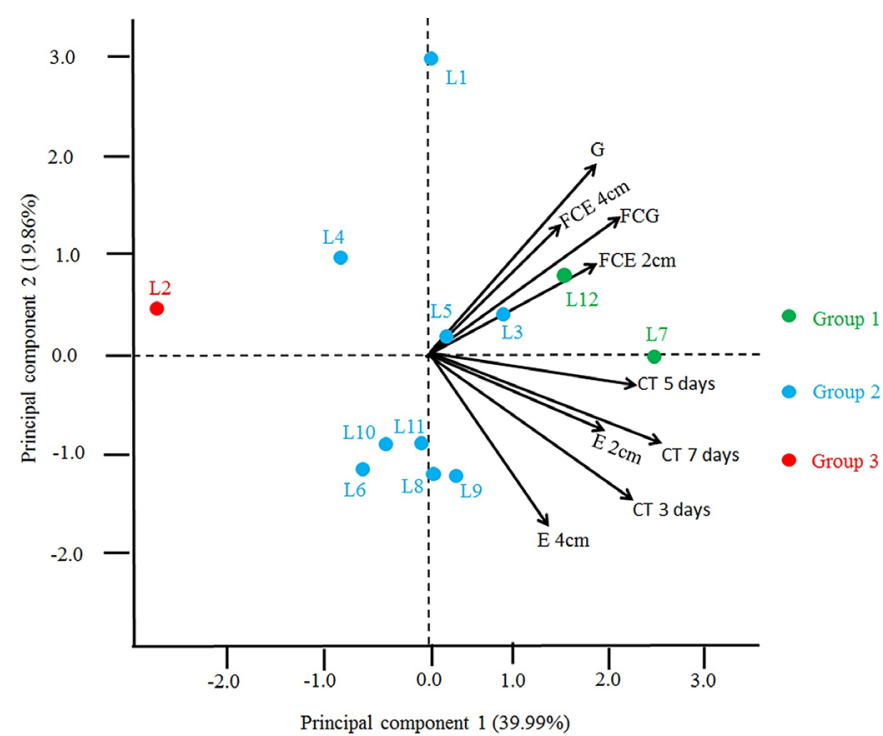

Figure 3. Dispersion of eigenvectors along a circular plane and formation of groups obtained by principal component analysis according to the variables: first count germination (FCG), germination (G), seedling emergence in field $2 \mathrm{~cm}(E 2$ $\mathrm{cm})$, first count seedling emergence in field $2 \mathrm{~cm}($ FCE $2 \mathrm{~cm})$, seedling emergence in field $4 \mathrm{~cm}(E 4 \mathrm{~cm})$, first count seedling emergence in field $4 \mathrm{~cm}$ (FCE $4 \mathrm{~cm}$ ), cold test 3 (CT 3 days), 5 (CT 5 days) and 7 (CT 3 days) days in the evaluation of 12 lots of safflower seeds.

\section{Conclusions}

The cold test at $10{ }^{\circ} \mathrm{C}$ for 7 days is recommended for evaluating the physiological quality of safflower seeds.

Multivariate principal component analysis is efficient in discriminating the vigor of safflower seed lots.

\section{Compliance with Ethical Standards}

Author contributions: Conceptualization: GZS, CGM, MVC; date curation: GZS, CGM; formal analysis: GZS, MVC; Funding acquisition: GZS, CGM, MVC; Investigation: GZS, CGM, MVC, IMHLS, RBOP, AASS, GFG; Methodology: GZS, CGM, MVC, IMHLS, RBOP, AASS, GFG; project administration: GZS, CGM; Resources: GZS, CGM, MVC; software: GZS, MVC; supervision: GZS, CGM; Validation: GZS, CGM, MVC; visualization: GZS, CGM, MVC; Writing - original draft: GZS, CGM, MVC; Writing review \& editing: GZS, CGM.

Conflict of interest: The authors declare that they have no conflicts of interest.

Financing source: This study was financed in part by the Coordenação de Aperfeiçoamento de Pessoal de Nível Superior - Brazil (CAPES) - Finance Code 001.

\section{Literature Cited}

Barbosa, R. M.; Vieira, B. G. T. L.; Ferraudo, A. S.; Corá, J. E.; Vieira, R. D. Discrimination of soybean seed lots by multivariate exploratory techniques. Journal of Seed Science, v.35, n.3, p.302-310, 2013. https://doi.org/10.1590/S2317-15372013000300005.
Barros, A. S.; Dias, M. C. L. L; Cicero, S. M.; Krzyzanowski, F. C. Testes de Frio. In: Krzyzanowski, F. C.; Vieira, R. D.; França-Neto, J. B. (Ed.). Vigor de sementes: conceitos e testes. Londrina: Abrates, 1999. p.5.1-5.15.

Berger, A. P. A.; Ranal, M. A.; Santana, D. G. Variabilidade na dormência relativa dos diásporos de Lithraea molleoides (Vell.) Eng. Ciência Florestal, v.24, n.2, p.1-13, 2014. https://doi. org/10.5902/1980509814570.

Bidgoly, R. O.; Balouchi, H.; Soltani, E.; Moradi, A. Effect of temperature and water potential on Carthamus tinctorius $\mathrm{L}$. seed germination: quantification of the cardinal temperatures and modeling using hydrothermal time. Industrial Crops \& Products, v.113, n.3, p.121-127, 2018. https://doi.org/10.1016/j. indcrop.2018.01.017.

Bonfim-Silva, E. M.; Paludo, J. T. S.; Sousa, J. V. R.; Sousa, H. H. F.; Silva, T. J. A. Development of Safflower sujected to nitogen rates in Cerrado soil. American Journal of Plant Sciences, v.6, n.13, p.2136-2143, 2015. https://doi.org/10.4236/ajps.2015.613215.

Brasil. Ministério da Agricultura, Pecuária e Abastecimento. Instrução normativa $n^{\circ} 45$, de 17 de setembro de 2013. Estabelece os padrões de identidade e qualidade para a produção e a comercialização de sementes de algodão, amendoim, arroz, arroz preto, arroz vermelho, aveia branca e amarela, canola, centeio, cevada, ervilha, feijão, feijão caupi, gergelim, girassol variedades, girassol cultivares híbridas, juta, linho, mamona variedades, mamona cultivares híbridas, milho variedades, milho cultivares híbridas, painço, soja, sorgo variedades, sorgo cultivares híbridas, tabaco, trigo, trigo duro, triticale e de espécies de grandes culturas inscritas no Registro Nacional de Cultivares RNC e não contempladas com padrão específico. Diário Oficial da União, v.150, n. 183, Seção 1, p. 6-27, 2013.

Brasil. Ministério da Agricultura, Pecuária e Abastecimento. Regras para análise de sementes. Ministério da Agricultura, Pecuária e Abastecimento. Secretaria de Defesa Agropecuária. Brasília: MAPA; ACS, 2009. 395p.

Campanella, L. C. D. A.; Silva, A. C.; Freygang, J.; Dal Magro, D. D. Efeito da suplementação de óleo de cártamo sobre o peso corporal, perfil lipídico, glicídico e antioxidante de ratos wistar induzidos a obesidade. Revista de Ciências Farmacêuticas Básica e Aplicada, v.35, n.1, p.141-147, 2015. https://rcfba.fcfar.unesp. br/index.php/ojs/article/view/167. 02 May. 2020.

Collins, M. E.; Ovalles, F. A. Variability of northwest Florida soils by principal component analysis. Soil Science Society of America Journal, v.5, n.8402, p.1430-1435, 1988. https://doi. org/10.2136/sssaj1988.03615995005200050042x.

Frandoloso, D. C. L.; Rodrigues, D. B.; Rosa, T. D. A.; Almeida, A. da S.; Soares, V. N.; Brunes, A. P.; Tunes, L. V. M. Qualidade de sementes de alface avaliada pelo teste de envelhecimento acelerado. Revista de Ciências Agrárias, v.40, n.4, p.703-713, 2017. https:// doi.org/10.19084/RCA17009.

Gama, G. F.; Machado, C. G.; Silva, G. Z.; Moraes, A. L. C.; Silva, A. A. S.; Silva, I. M. H. L. Substrates and duration for conducting the safflower seed germination test. Científica, v.47, n.4, p.426-433, 2019. https://doi.org/10.15361/19845529.2019v47n4p426-433. 
Instituto Nacional de Meteorologia - INMET. Tempo. http:// www.inmet.gov.br/portal/index.php?r=estacoes/ estacoesAutomaticas. 20 Mar. 2020.

Kaya, M. D.; Kulan, E. G.; Ileri, O.; Avci, S. Prediction of viability and emergence capacity of safflower seed lots. The Journal of Animal \& Plant Sciences, v.29, n.3, p.714-720, 2019. http://www.thejaps. org.pk/docs/Accepted/2019/29-03/03.pdf. 13 May. 2020.

Lorentz, L H.; Nunes, U. R. Relações entre medidas de qualidade de lotes de sementes de arroz. Revista Ciência Agronômica, v.44, n.4, p.798-804, 2013. https://doi.org/10.1590/S180666902013000400017.

Maguire, J. D. Speed of germination-aid in selection and evaluation for seedling emergence and vigor. Crop Science, v.2, n.1, p.176-177, 1962. https://doi.org/10.2135/ cropsci1962.0011183X000200020033x.

Marcos Filho, J. Seed vigor testing: an overview of the past, present and future perspective. Scientia Agrícola, v.72, n.4, p.363-374, 2015. https://doi.org/10.1590/0103-9016-2015-0007.

Maziero, C. L.; Santos, R. F.; Bassegio, D.; Lewandoski, C. F.; Bueno, P. L.; Benetoli, T. R.; Secco, D.; Souza, S. M. N.; Souza, D. M.; Rosseto, R. E. Initial growth and agronomic performance of some important North American safflower cultivars. Australian Journal of Crop Science, v.13, n.5, p.726-731, 2019. https://doi. org/10.21475/ajcs.19.13.05.p1414.
Oliveira, J. D. de; Silva, J. B. da; Alves, C. Z. Tratamentos para incrementar, acelerar e sincronizar a emergência de plântulas de mucuna-preta. Revista Ciência Agronômica, v.48, n.3, p.531-539, 2017. https://doi.org/10.5935/1806-6690.20170062.

Rencher, A. C.; Christensen, W. F. Methods of multivariate analysis. New York: John Wiley Professio, 2012. 758p.

Santana, D. G.; Ranal, M. A. Análise da germinação: um enfoque estatístico. Brasília: Editora Universidade de Brasília, 2004. 248p.

Silva, G. Z.; Martins, C. C.; Bruno, R. L. A.; Pereira, F. E. C. B.; Jeromini, T. S. Multivariate analysis and vigor tests to determine the quality of Brachiaria decumbens seeds. Revista Ciência Agronômica, v.50, n.2, p.291-299, 2019. https://doi.org/10.5935/18066690.20190034 .

Singh, V.; Nimbkar, N. Safflower. In: Gupta, S. K. (Eds.). Breeding oilseed crops for sustainable production. San Diego: Academic Press, 2016. p.147-165.

Soleymani, A. Safflower (Carthamus tinctorius L.) seed vigor tests for the prediction of field emergence. Industrial Crops and Products, v.131, p.378-386, 2017. https://doi.org/10.1016/j. indcrop.2017.03.022.

Yao, Y.; Yao, J.; Du, Z.; Wang, P.; Ding, K. Structural elucidation and immune-enhancing activity of an arabinogalactan from flowers of Carthamus tinctorius L. Carbohydrate Polymers, v.202, p.134142, 2018. https://doi.org/10.1016/j.carbpol.2018.08.098. 